\title{
The Development of the Text Evaluation Scale for Child Rights: A Study of Validity and Reliability
}

\author{
Yusuf Söylemez, ${ }^{1, *}$ \\ ${ }^{1}$ Faculty of Science and Letters, Department of Literature, Ağrı İbrahim Çeçen University, Ağrı, Turkey \\ *Correspondence: Faculty of Science and Letters, Department of Literature, Ağrı İbrahim Çeçen University, Ağrı, \\ Turkey. E-mail: yusuf.soylemez25@yandex.com
}

Received: September 7, 2018

Accepted: September 28, $2018 \quad$ Online Published: October 17, 2018

doi:10.5430/wje.v8n5p139

URL: https://doi.org/10.5430/wje.v8n5p139

\begin{abstract}
This study was conducted with the aim of developing The Text Evaluation Scale for Child Rights. There are four different sample chosen for the face validity, content validity and construct validity (for pilot scheme and main study) of the study. For face validity, a sample group of 3 experts chosen with the method of purposeful sampling including the researcher was formed. For content validity, snowball method was determined and studied with 12 experts. For the study of construct validity, random sampling method was performed for the sample selection in pilot study involving 120 people and in main study involving 510 people.

The theoretical framework of the scale was determined by means of the attempts, conventions, studies regarding the subject basing upon the United Nations Organization Child Rights Convention and additional protocols to this convention. One could get minimum 40 and maximum 200 points from the five-point Likert scale which consists of 28 positive and 12 negative (total 40) items. The scale has two sub-dimensions which are content and author. The fact that Cronbach Alpha reliability coefficient is high regarding the sub-dimensions of the scale (author sub-dimension $=0,822$ content sub-dimension $=0,834$ ) shows that the items in the sub-dimensions are consistent with one another. Cronbach Alpha value for the whole of the scale was determined as 0,90 which means that the scale is highly reliable. Besides, in the scale, there are items of which factor loading value is higher than 0,45 . When validity and reliability results are examined, it can be seen that the scale could be utilized to evaluate the text in terms of being suitable for the child rights.
\end{abstract}

Keywords: scale development, reliability, validity, child rights, text evaluation scale

\section{Introduction}

Child is defined as a human in the growing period between the babyhood and puberty (http://www.tdk.gov.tr). As for the United Nations Organization Child Rights Convention, every individual is accepted as child until s/he is 18 years old (MEB, 1991: 12). Differently from the baby notion, child notion is a period involving social and cultural elements and it is regarded as a period in which it is possible to start to live without being dependent to the parents (Akyüz, 2010: 1). Defined as "small man" or "little man" is a social constitute who is not cared and mostly in the growing process (Torun, 2011: 8). The child who sometimes is exposed to sex discrimination, regarded important according to his/her gender, given or not given the right of succession, accepted as a source of either shame or honor is the most exploited constitute also in the war times (Kara, Biçer\& Gökalp, 2004: 140-141).

A child is considered as the one who has the right to benefit from the human rights, even though it is not found enough, also as an individual who has special and different needs from the adults and the constituent who builds the future of the society. Hence, nations in the modern world take international steps to entitle the child special rights and to protect these rights, and they sign conventions.

It is important for the structures comprising text or texts such as books or training materials, which play an important role in child education, to have sensitivity for child rights and to be adequately prepared for this. The fact that there should be a scale which makes it possible to evaluate the texts in terms of the child rights should be considered as equally important. As these evaluations increase, published books and texts designed or chosen for training materials would be more content-rich in terms of being suitable for child rights, even for teaching child rights. 


\section{Literature Review}

Knowledge is synonymous to awareness, learning, education and cognizance (Adeyemi, Roseline, Ocheje, 2015: 71). Having rights is a concept which could exist culturally in the society not spontaneously in the nature (Kara, Biçer\& Gökalp, 2004: 140-141). Therefore, considering the child as a right owner is related to the society and the structure of the society. In the medieval ages, children were individuals wearing like the adults and judged like adults when they committed crimes. Having started to have a different identity after renaissance, children were started to seen as symbol of innocence. They started to have their own stories and plays. The opportunity of the families to reach libraries and books became a source of privilege for the children, too (Yıldırım\& Şimşek, 2018). While it was the case for the children in belonging to middle class and upper class, children in the low-income groups took place as individuals who were the stakeholders of the burden of their families and were wearing the minimized clothes of the adults (Postman, 1995, cited by Torun, 2011: 8).

Reading is crucial in the development and improvement of people's mind (Oriogu, 2015: 61). So the child starts to have an exact identity in the twentieth century. The idea that children have different emotions and thought from the adults raised. The facts that pedagogues, philosophers, legists and educators started to examine the children and that the ideas about the child rights and growth made this period important (Yurtsever, 2009: 14-15). The perception dominant in the $20^{\text {th }}$ century is that children have their own biological category and they are different from the adults; as being adult is an acquisition children should be prepared for this; this responsibility belongs to the adults. (Tan, 1993 cited by Yurtsever, 2009: 22).

In 1919, Custody of Infants Act was established to protect the children in England after The First World War. Jebb, working for this act prepared a draft for child rights in 1922. In this draft, responsibilities against children such as protection of them against the exploitation, providing them with fully physical, cognitive and moral development regardless of their nation, race and religion was mentioned. Later on, this draft was accepted as Geneva Declaration of the Rights of the Child by United Nations in 1924. Geneva Declaration of the Rights of the Child was the first international document for the protection of the child rights (Kurt, 2013: 16; Yurtsever, 2009: 32).

Second World War starting in 1939 caused Child Rights Convention no to go beyond being just on the paper (Müftü, 2001: 7). The fact that child abuse raised worldwide following the Second World War forced countries to take special precautions for the benefit of the children. In this context, firstly in 1959, Child Rights Declaration was revealed by the United Nations General Assembly, and then in 1989, a more detailed work was put forward with Child Rights Convention. Child Rights Convention which was opened for signature in January 20, 1990, was signed by 61 countries at the same time. Turkey signed the convention, in the "World Summit for Children" gathered in United Nation General Center by making reservation for Articles 17, 29, and 30. The convention which was found suitable to confirm with the law no 4058 come into force in January 27, 1995 after it was published in official gazette.

When United Nations Child Rights Convention is examined in terms of its content, it could be said that it was structured on the themes of "Education, Leisure Time and Cultural Activities", "Family Environment and Care", "Basic Health and Welfare" and "Civil rights and Freedom." (Yurtsever, 2009: 67). Reading is one of the most important skills (Migdadi, Baniabdelrahman, 2016: 39). According to the text, every child has the right to be recorded with the name given by their parents, to stay with their parents and to be cared by them. If they are insufficient, the state is responsible to provide the essential conditions for the children, in which a child can develop physically and cognitively. The care, health, welfare and the identity rights of the children, who are disabled, abandoned, separated from their families permanently or temporarily, are also under the assurance of the state. A child has the freedom of thought and faith. Children could tell their ideas liberally, own documents and share them, join art organizations and meet up peacefully. Contracting countries promised to provide this. The convention which covers many rights from living, the most basic right of the children, to the games, regards the child as an individual who has his/her own rights, freedom and boundaries and protects them.

The purpose of this study is to develop a reliable and valid scale which would help to evaluate the texts, prepared for children, with respect to the child rights. In accordance with this purpose, the research question was performed as follows:

"Is it possible to develop a reliable and valid scale which could be used to evaluate the texts, prepared for children, with respect to the child rights?" 


\section{Methodology}

The study was conducted according to the exploratory design among mixed methods. Qualitative data were gathered via document analysis and analyzed with the method of content analysis. As for the quantitative data, they were gathered through scanning method and analyzed with a statistical package.

The study was conducted within the mixed method framework. In this method, in which qualitative and quantitative research methods are used together, different designs could be determined according to the order and importance of quantitative and qualitative data.

\subsection{Design}

The study was planned and conducted according to exploratory design on the basis of mixed method. Scientific studies are conducted according to quantitative and qualitative method; however, some studies make it necessary to combine these two methods. As both of these methods are utilized in these studies, they are called mixed method studies (Creswell and Plano Clark, 2014: 3). Mixed method studies consist of different designs according to the aim and type of the research, and to the conditions such as the way or sequence that quantitative and qualitative data are utilized. Due to the fact that this study setting out from the quantitative data aims to develop a qualitative research tool which could be used in the future studies, exploratory sequential design was used (Creswell and Plano Clark, 2014: 96).

Table 1. The Scale Development Model Used in the Study

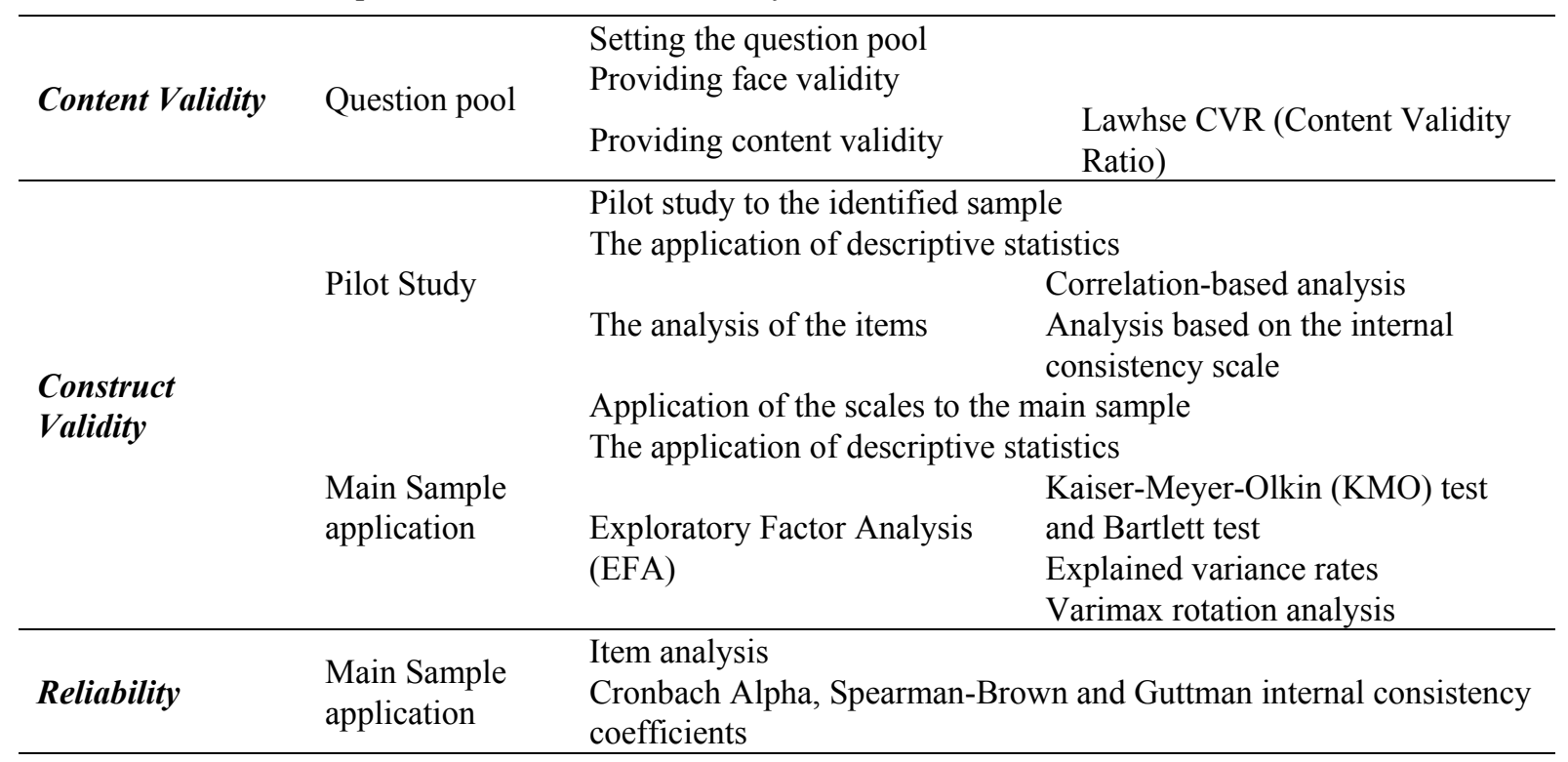

Question pool is somehow the draft of the assessment instrument to be developed. The items should be prepared in a conceptual framework regarding all sub-dimensions of the structure which is intended to be assessed (Comrey, 1988: 755; cited by Şahin, 2009). Therefore, international attempts for the child rights, conventions, especially United Nations Child Rights Convention, additional protocols and studies in the literature related to the subject were examined. When the case is to generate questions, two ways, inductive and deductive, could be followed (Hinkin, 1995: 969). Because especially United Nations Child Rights Convention was approached in the study, deductive method was preferred. As there would be $35-40$ items in the aimed final scale form, it is necessary for question pool to consist of at least three times higher number of items (Şencan, 2005: s. 750). For this reason, a question pool involving 142 items consisting of positive and negative question roots was formed.

After forming the question pool, face validity was studied by the researcher and two people who are experts in the field of Turkish language education. Face validity is about how the scale seems to assess when it is examined by the attendant of the scale (DeVellis, 2003: 57). In face validity, the opinions of the participants about the subjects such as the clarity of the items, their length and being easy to read and answer are evaluated (Karakoç\& Dönmez, 2014).

For the draft scale, which has face validity, content validity was studied with 12 people who are experts in the fields of Turkish Language education, child development, assessment and evaluation. Calculating the Content Validity 
Ratio (CVR) developed by Lawshe, it was determined whether scale items are covering the subjects about child rights.

The draft, which has content validity, was tested over two different sample groups. Firstly, pilot study was performed to the sample group $(n=120)$ which was chosen via the purposive sampling method and excluded from the main sample group. The scale was put into final form by performing analysis of the obtained data via a statistical package basing upon correlation and internal validity standards.

Following the pilot study, the scale was tested on the main sample group $(n=510)$ which had been determined with the random sampling method. Exploratory Factor Analysis (EFA) was performed; construct validity was provided with Kaiser-Meyer-Olkin (KMO) test and Bartlett test, explained variance rates and Varimax rotation analysis. For reliability, item analysis was performed and Cronbach Alpha, Spearman-Brown and Guttman internal consistency coefficients were examined. Finally, it was decided to be a valid and reliable assessment tool.

\subsection{Population and Sample}

Research population consists of teachers working in National Education Directorate of Erzurum, last grade undergraduates from Ataturk University and academicians working at the same university.

The present study, which is a study of scale development, has four different sample groups. The first group is the expert group who help to provide face validity. It consists of the researcher and two people who are experts in the field of Turkish language education.

The second group was the expert group who helps to provide content validity. Expert group was determined with snowball sampling technique and it consisted of 12 people who are experts in the fields of Turkish Language education, child development, assessment and evaluation.

Third sample group consisted of 120 participants who were determined by purposive sampling who are not included in the main study sample group. Demographic features of the sample are given in Table 2.

Table 2. Demographic Features of the Sample Group That the Pilot Study Was Applied

\begin{tabular}{|c|c|c|c|c|}
\hline & & \multicolumn{3}{|c|}{ Occupational Group } \\
\hline & & Undergraduate & Teacher & Academician \\
\hline \multirow{3}{*}{ 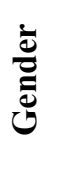 } & Women & 24 & 14 & 12 \\
\hline & Men & 30 & 20 & 20 \\
\hline & Total & 54 & 34 & 32 \\
\hline
\end{tabular}

The fourth group was the main sample group on which the assessment instrument was tested. Demographic features of this sample group consisting of 510 participants determined via random sampling method are given in Table 3 .

Table 3. Demographic Features of the Sample Group That the Main Study Was Applied

\begin{tabular}{ccccc}
\hline & & \multicolumn{3}{c}{ Occupational Group } \\
\cline { 3 - 5 } & Women & 120 & Teacher & Academician \\
\hline \multirow{0}{*}{$\bar{D}$} & Men & 142 & 100 & 30 \\
$\overline{0}$ & Total & 262 & 180 & 38 \\
\hline
\end{tabular}

\section{Results}

The findings obtained from the study are examined under the four titles; face validity, content validity, construct validity and reliability 


\subsection{Face Validity}

Face validity includes the stage of extraction or restoration of the parts of the scales which are repeating, irrelevant or incoherent after the questions in the question pool are evaluated with respect to such features as language, meaning, punctuation etc. After the researcher and two people who are experts in the field of Turkish language education studied face validity, from the question pool consisting of 142 items, it was decided to extract 25 of 50 recurrent items and 20 items that included irrelevant and specific expressions. Out of the 21 items, which are thought to have intelligibility problems, 15 items were extracted from the scale and 6 were refined. The items having punctuation and spelling problems were refined and the first draft consisting of 82 items was made.

\subsection{Content Validity}

Content validity is about the validity of the instrument and the correlation between the feature intended to assess and scale items. To provide content validity, Lawshe's Content Validity Ratio was decided (Lawshe, 1975). According to this, content validity rates are obtained by getting the opinions of the experts about any of the items. Content Validity Rates (CVR) is calculated by subtracting 1 from the rate of the number of the experts, who indicates their "necessary" recommendations for an item, to the total number of the experts. The minimum values of CVRs (content validity criteria) were converted to a table by Veneziano and Hooper (1997) at the significance level of $\alpha=0,05$ so that it could be calculated easily. Accordingly, minimum values about the number of the experts also give the statistical significance of the item (Yurdugül, 2005; Sevim, 2014; Erdemir, 2007).

Table 4. Minimum Values at the Significance Level of $\alpha=0,05$ for CVRs

\begin{tabular}{cccc}
\hline $\begin{array}{c}\text { Number of } \\
\text { the Experts }\end{array}$ & Minimum Value & $\begin{array}{c}\text { Number of } \\
\text { the Experts }\end{array}$ & Minimum Value \\
\hline $\mathbf{5}$ &, 99 & 13 &, 54 \\
$\mathbf{6}$ &, 99 & 14 &, 51 \\
$\mathbf{7}$ &, 99 & 15 &, 49 \\
$\mathbf{8}$ &, 78 & 20 &, 42 \\
$\mathbf{9}$ &, 75 & 25 &, 37 \\
$\mathbf{1 0}$ &, 62 & 30 &, 33 \\
$\mathbf{1 1}$ &, 59 & 35 &, 31 \\
$\mathbf{1 2}$ &, 56 & $40+$ &, 29 \\
\hline
\end{tabular}

In the study of content validity conducted with 12 experts, when the Table 4 is examined it is necessary to refine the items under the value of 56 if possible; if it not possible it is necessary to extract them from the scale.

The data obtained from the content validity study conducted with 12 experts are given in Table 5 .

Table 5. Content Validity Rates of the Text Evaluation Scale for Child Rights

\begin{tabular}{lcccc}
\hline $\begin{array}{l}\text { Item } \\
\text { Number }\end{array}$ & Essential & $\begin{array}{c}\text { Should be } \\
\text { refined }\end{array}$ & $\begin{array}{c}\text { Should be } \\
\text { extracted }\end{array}$ & CVR \\
\hline $\mathbf{1}$ & 10 & & 2 & 0,67 \\
$\mathbf{2}$ & 5 & 2 & 5 & $-0,17$ \\
$\mathbf{3}$ & 8 & 1 & 3 & 0,33 \\
$\mathbf{4}$ & 9 & & 3 & 0,50 \\
$\mathbf{5}$ & 10 & 1 & 1 & 0,67 \\
$\mathbf{6}$ & 11 & & 1 & 0,83 \\
$\mathbf{7}$ & 12 & & 0 & 1,00 \\
$\mathbf{8}$ & 11 & & 1 & 0,83 \\
$\mathbf{9}$ & 11 & & 1 & 0,83 \\
\hline
\end{tabular}




\begin{tabular}{|c|c|c|c|c|}
\hline 10 & 11 & & 1 & 0,83 \\
\hline 11 & 11 & 1 & 0 & 0,83 \\
\hline 12 & 12 & & 0 & 1,00 \\
\hline 13 & 10 & & 2 & 0,67 \\
\hline 14 & 10 & & 2 & 0,67 \\
\hline 15 & 9 & & 3 & 0,50 \\
\hline 16 & 8 & & 4 & 0,33 \\
\hline 17 & 9 & & 3 & 0,50 \\
\hline 18 & 4 & 1 & 7 & $-0,33$ \\
\hline 19 & 5 & & 7 & $-0,17$ \\
\hline 20 & 6 & & 6 & 0,00 \\
\hline 21 & 6 & & 6 & 0,00 \\
\hline 22 & 7 & 1 & 4 & 0,17 \\
\hline 23 & 9 & & 3 & 0,50 \\
\hline 24 & 11 & & 1 & 0,83 \\
\hline 25 & 12 & & 0 & 1,00 \\
\hline 26 & 10 & 1 & 1 & 0,67 \\
\hline 27 & 10 & & 2 & 0,67 \\
\hline 28 & 12 & & 0 & 1,00 \\
\hline 29 & 11 & & 1 & 0,83 \\
\hline 30 & 6 & & 6 & 0,00 \\
\hline 31 & 7 & & 5 & 0,17 \\
\hline 32 & 10 & & 2 & 0,67 \\
\hline 33 & 12 & & 0 & 1,00 \\
\hline 34 & 8 & & 4 & 0,33 \\
\hline 35 & 7 & & 5 & 0,17 \\
\hline 36 & 5 & & 7 & $-0,17$ \\
\hline 37 & 12 & & 0 & 1,00 \\
\hline 38 & 11 & 1 & 0 & 0,83 \\
\hline 39 & 11 & & 1 & 0,83 \\
\hline 40 & 10 & 2 & 0 & 0,67 \\
\hline 41 & 10 & & 2 & 0,67 \\
\hline 42 & 12 & & 0 & 1,00 \\
\hline 43 & 12 & & 0 & 1,00 \\
\hline 44 & 12 & & 0 & 1,00 \\
\hline 45 & 11 & & 1 & 0,83 \\
\hline 46 & 11 & & 1 & 0,83 \\
\hline 47 & 10 & & 2 & 0,67 \\
\hline 48 & 11 & & 1 & 0,83 \\
\hline 49 & 11 & & 1 & 0,83 \\
\hline 50 & 10 & & 2 & 0,67 \\
\hline
\end{tabular}




\begin{tabular}{|c|c|c|c|c|}
\hline 51 & 12 & & 0 & 1,00 \\
\hline 52 & 12 & & 0 & 1,00 \\
\hline 53 & 12 & & 0 & 1,00 \\
\hline 54 & 11 & & 1 & 0,83 \\
\hline 55 & 10 & & 2 & 0,67 \\
\hline 56 & 10 & & 2 & 0,67 \\
\hline 57 & 9 & & 3 & 0,50 \\
\hline 58 & 8 & 1 & 3 & 0,33 \\
\hline 59 & 9 & & 3 & 0,50 \\
\hline 60 & 8 & & 4 & 0,33 \\
\hline 61 & 11 & & 1 & 0,83 \\
\hline 62 & 12 & & 0 & 1,00 \\
\hline 63 & 10 & 2 & 0 & 0,67 \\
\hline 64 & 12 & & 0 & 1,00 \\
\hline 65 & 11 & & 1 & 0,83 \\
\hline 66 & 11 & & 1 & 0,83 \\
\hline 67 & 12 & & 0 & 1,00 \\
\hline 68 & 12 & & 0 & 1,00 \\
\hline 69 & 10 & & 2 & 0,67 \\
\hline 70 & 11 & & 1 & 0,83 \\
\hline 71 & 12 & & 0 & 1,00 \\
\hline 72 & 12 & & 0 & 1,00 \\
\hline 73 & 9 & & 3 & 0,50 \\
\hline 74 & 8 & 2 & 2 & 0,33 \\
\hline 75 & 11 & & 1 & 0,83 \\
\hline 76 & 10 & & 2 & 0,67 \\
\hline 77 & 8 & & 4 & 0,33 \\
\hline 78 & 9 & & 3 & 0,50 \\
\hline 79 & 8 & & 4 & 0,33 \\
\hline 80 & 8 & & 4 & 0,33 \\
\hline 81 & 10 & 1 & 1 & 0,67 \\
\hline 82 & 11 & & 1 & 0,83 \\
\hline \multicolumn{4}{|c|}{ The number of the Experts } & 12 \\
\hline \multicolumn{4}{|c|}{ Content Validity Standard } & 0,56 \\
\hline \multicolumn{4}{|c|}{ Content Validity Index } & 0,67 \\
\hline
\end{tabular}

When table 5 is examined and CVR $\geq, 56$ is based for CVR value, it can be seen that items with number 2, 3, 4, 15, $16,17,18,19,20,21,22,23,30,31,34,35,36,57,58,59,60,73,74,77,78,79,80$ are under this value. As a result of the evaluation, it is decided to extract all of these items from the scale. Inasmuch as the average of the rest of the items is, 84 and close to exact 1 value, it could be claimed that average content validity is high. 


\subsection{Construct Validity}

\subsubsection{Pilot Study}

In order to provide the construct validity of the second draft which has content validity, firstly pilot study was performed. Researchers indicate that pilot studies could be performed with sample groups of 30-50 people (Şeker and Gençdoğan, 2006: 13) and that these numbers could be increased so as to increase the reliability of the data (Özgüven, 2012). Therefore, a sample group consisting of 120 participants was studied. In Table 6, some of the descriptive statistics related to the range features of the points belonging to the Text Evaluation Scale for Child Rights are shown.

Table 6. Descriptive Statistics of the Text Evaluation Scale for Child Rights

\begin{tabular}{ll}
\hline Descriptive Statistics & \\
\hline $\mathbf{N}$ & 120 \\
Mean & 178,640 \\
Std. Error of Median & 3,82456 \\
Median & 160,00 \\
Mode & 149 \\
Std. Deviation & 18,65314 \\
Variance & 347,939 \\
Skewness &, 013 \\
Kurtosis &, 045 \\
Range & 191,00 \\
Minimum & 108,00 \\
Maximum & 257,00 \\
Sum & 21436,8 \\
\hline
\end{tabular}

In table 6 where descriptive statistics of Text Evaluation Scale for Child Rights are given, there are 54 items and they are coded as strongly disagree, disagree, neither agree nor disagree, agree, strongly agree, and they are given points from 1 to 5 in the same sequence. On the other hand, negative items are graded reversely. The lowest possible score in the test is 54 and the highest is 270 . The range is expected to be $(270-54=) 216$ so that the scale could cover all of the skill items from the most positive point of the related skill to the most negative point of it; however, it can be seen that range is 191 in the pilot study. Now then, it is seen that the draft scale covers some parts of the expected range. The mean of the data, obtained in the pilot study as measures of central tendency, is 178,64; the median is 160 and the mode is 149 which are very close to each other. It is determined that range informing about how the data are distributed around the measures of central tendency is 191 while standard deviation is 18,65 . Showing the distribution rates of points and values, these obtained measures of tendency has revealed that the participants of the pilot study are homogenous in terms of the assessed features.

Item analysis method was used to determine whether the items of the scale assess the conceptual structure consistently. Firstly, the total correlation coefficients of the Text Evaluation Scale for Child Rights were examined. In table 7, total correlation coefficients of the items in the scale are given.

In table 7, Pearson Product Moment Correlation coefficients calculated between the range of item points and the range of scale point are present. When table 7 is examined, the item which has the highest scale value (item-test correlation) is Item 28 while the item which has the lowest scale value (item-test correlation) is Item 5 . In other words, according to the scale values basing upon the reactions of the participants, Item 28 is the best item which assesses the intended feature while Item 5 assesses the intended feature at the minimum level.

When the values in Table 7 are regarded, it is seen that coefficient values vary between the values of $-0,125$ and 0,794 . It is understood that 2 items (Item 5 and Item 32) have revealed negative value coefficient. It was revealed that in addition to 2 items (Item 5 and Item 32) which have negative value coefficient, the coefficient values of 3 items (Item 8, Item 37 and Item 44) are less than 0.30. 
Table 7. The Total Correlation Coefficients of the Text Evaluation Scale for Child Rights

\begin{tabular}{|c|c|c|c|}
\hline Item & $\mathbf{X}$ & SS & $\mathbf{r}$ \\
\hline Item 5 & 4,06 & 0,76 &,- 125 \\
\hline Item 32 & 2,96 & 0,18 &,- 110 \\
\hline Item 37 & 4,80 & 0,97 & ,201 \\
\hline Item 44 & 3,85 & 1,78 & ,246 \\
\hline Item 8 & 4,22 & 0,81 & ,254 \\
\hline Item 36 & 3,94 & 0,91 & ,325 \\
\hline Item 30 & 3,86 & 0,86 & ,328 \\
\hline Item 38 & 4,02 & 1,54 & ,328 \\
\hline Item 43 & 2,25 & 0,67 & ,328 \\
\hline Item 14 & 4,07 & 0,91 & ,330 \\
\hline Item 16 & 3,92 & 0,98 & ,330 \\
\hline Item 34 & 4,03 & 0,86 & ,330 \\
\hline Item 46 & 2,30 & 0,20 & ,348 \\
\hline Item 18 & 3,44 & 1,87 & ,350 \\
\hline Item 54 & 3,14 & 0,76 & ,354 \\
\hline Item 52 & 4,67 & 0,91 & ,355 \\
\hline Item 10 & 2,60 & 1,21 & ,356 \\
\hline Item 11 & 2,65 & 1,54 & ,356 \\
\hline Item 53 & 3,80 & 1,31 & ,356 \\
\hline Item 4 & 3,85 & 1,25 & ,359 \\
\hline Item 41 & 4,11 & 1,24 & ,359 \\
\hline Item 19 & 2,97 & 0,86 & ,361 \\
\hline Item 40 & 4,58 & 1,86 & ,366 \\
\hline Item 33 & 3,66 & 1,91 & ,378 \\
\hline Item 42 & 4,72 & 0,97 & ,378 \\
\hline Item 47 & 3,38 & 1,98 & ,378 \\
\hline Item 29 & 1,44 & 1,50 & ,380 \\
\hline Item 6 & 2,97 & 0,91 & ,382 \\
\hline Item 24 & 4,64 & 1,45 & ,382 \\
\hline Item 35 & 3,88 & 0,76 & ,382 \\
\hline Item 50 & 4,22 & 1,54 & ,382 \\
\hline Item 1 & 3,89 & 0,66 & ,385 \\
\hline Item 49 & 3,56 & 0,76 & ,385 \\
\hline Item 22 & 2,90 & 0,97 & ,392 \\
\hline Item 48 & 4,46 & 0,87 & ,399 \\
\hline Item 21 & 3,98 & 0,76 &, 420 \\
\hline Item 27 & 4,25 & 0,78 &, 420 \\
\hline Item 31 & 4,73 & 0,42 & ,420 \\
\hline Item 25 & 3,04 & 0,80 &, 421 \\
\hline
\end{tabular}




\begin{tabular}{llll}
\hline Item 39 & 4,20 & 1,42 &, 423 \\
Item 17 & 2,23 & 1,31 &, 424 \\
Item 7 & 3,98 & 0,86 &, 449 \\
Item 12 & 4,38 & 1,54 &, 455 \\
Item 15 & 4,08 & 0,81 &, 463 \\
Item 13 & 4,83 & 1,32 &, 472 \\
Item 45 & 3,69 & 0,86 &, 472 \\
Item 26 & 3,54 & 0,76 &, 480 \\
Item 2 & 2,68 & 0,93 &, 485 \\
Item 23 & 3,84 & 1,42 &, 505 \\
Item 3 & 4,51 & 1,42 &, 556 \\
Item 51 & 2,79 & 1,86 &, 558 \\
Item 20 & 4,52 & 0,85 &, 582 \\
Item 9 & 4,98 & 0,62 &, 615 \\
Item 28 & 3,24 & 0,52 &, 794 \\
\hline
\end{tabular}

Moreover, discrimination power of every item was analyzed. It was examined whether every item in the Text Evaluation Scale for Child Rights, in a statistically significant level, discriminate the group (high critical visual reading level) which is present in the top 27 percent of the sample on the basis of the total points and the group (low critical visual reading level) which is present in bottom $27 \%$ of the sample group. For this, the points of these two extreme groups were compared via $t$ test technique.

Table 8. Related to the Significance of the Averages of Top and Bottom Groups, t Test Results of the Range of the Every Item in Text Evaluation Scale for Child Rights

\begin{tabular}{llllllll}
\hline Item & Group & $\mathbf{N}$ & $\mathbf{X}$ & $\mathbf{S}$ & $\mathbf{d . f .}$ & $\mathbf{t}$ & $\mathbf{p}$ \\
\hline Item 1 & Top & 32 & 3,42 &, 869 & 77 & 2,982 &, 000 \\
& Bottom & 32 & 3,13 &, 354 & & & \\
Item 2 & Top & 32 & 4,74 & 1,588 & 77 & 3,170 &, 001 \\
& Bottom & 32 & 3,36 & 1,011 & & & \\
Item 3 & Top & 32 & 3,42 &, 951 & 77 & 5,502 &, 001 \\
& Bottom & 32 & 2,90 & 1,035 & & & \\
Item 4 & Top & 32 & 3,42 & 1,128 & 77 & 6,236 &, 000 \\
& Bottom & 32 & 3,13 & 1,385 & & & \\
Item 5 & Top & 32 & 4,74 &, 572 & 77 & 2,387 &, 102 \\
& Bottom & 32 & 3,36 &, 914 & & & \\
Item 6 & Top & 32 & 3,42 & 1,456 & 77 & 4,507 &, 000 \\
& Bottom & 32 & 2,90 & 1,974 & & & \\
Item 7 & Top & 32 & 4,12 &, 874 & 77 & 5,004 &, 000 \\
& Bottom & 32 & 3,87 & 1,978 & & & \\
Item 8 & Top & 32 & 3,44 & 1,347 & 77 & 3,668 &, 163 \\
& Bottom & 32 & 3,77 & 1,348 & & & \\
Item 9 & Top & 32 & 3,46 & 1,201 & 77 & 2,920 &, 005 \\
& Bottom & 32 & 4,28 &, 135 & & & \\
Item 10 & Top & 32 & 4,50 & 1,486 & 77 & 5,357 &, 000 \\
& Bottom & 32 & 3,30 & 1,541 & & & \\
Item 12 & Top & 32 & 3,42 &, 367 & 77 & 4,581 &, 000 \\
& Bottom & 32 & 2,31 &, 714 & & & \\
Item 13 & Top & 32 & 3,47 &, 895 & 77 & 2,984 &, 000 \\
& Bottom & 32 & 3,42 & 1,784 & & & \\
\hline
\end{tabular}




\begin{tabular}{|c|c|c|c|c|c|c|c|}
\hline \multirow[t]{2}{*}{ Item 14} & Top & 32 & 4,37 & ,702 & 77 & 4,433 & ,000 \\
\hline & Bottom & 32 & 2,20 & 1,635 & & & \\
\hline \multirow[t]{2}{*}{ Item 15} & Top & 32 & 3,72 & 1,380 & 77 & 5,392 &, 000 \\
\hline & Bottom & 32 & 2,37 & 1,322 & & & \\
\hline \multirow[t]{2}{*}{ Item 16} & Top & 32 & 4,85 & 989 & 77 & 4,030 & ,000 \\
\hline & Bottom & 32 & 3,10 & ,790 & & & \\
\hline \multirow[t]{2}{*}{ Item 17} & Top & 32 & 4,32 & 1,352 & 77 & 3,248 & ,014 \\
\hline & Bottom & 32 & 3,52 & 1,837 & & & \\
\hline \multirow[t]{2}{*}{ Item 18} & Top & 32 & 2,42 & 1,847 & 77 & 2,025 & ,000 \\
\hline & Bottom & 32 & 1,29 & ,645 & & & \\
\hline \multirow[t]{2}{*}{ Item 19} & Top & 32 & 3,89 & 1,412 & 77 & 2,370 &, 000 \\
\hline & Bottom & 32 & 3,19 & 1,209 & & & \\
\hline \multirow[t]{2}{*}{ Item 20} & Top & 32 & 3,21 & 605 & 77 & 2,804 &, 011 \\
\hline & Bottom & 32 & 2,28 & ,507 & & & \\
\hline \multirow[t]{2}{*}{ Item 21} & Top & 32 & 3,36 & 1,484 & 77 & 6,421 & ,001 \\
\hline & Bottom & 32 & 2,65 & ,836 & & & \\
\hline \multirow[t]{2}{*}{ Item 22} & Top & 32 & 3,18 & 1,449 & 77 & 2,502 &, 000 \\
\hline & Bottom & 32 & 2,68 & 1,427 & & & \\
\hline \multirow[t]{2}{*}{ Item 23} & Top & 32 & 3,51 & ,330 & 77 & 4,711 &, 000 \\
\hline & Bottom & 32 & 3,00 & ,442 & & & \\
\hline \multirow[t]{2}{*}{ Item 24} & Top & 32 & 3,63 & 1,255 & 77 & 4,920 &, 000 \\
\hline & Bottom & 32 & 2,02 & ,461 & & & \\
\hline \multirow[t]{2}{*}{ Item 25} & Top & 32 & 3,77 & 1,230 & 77 & 5,902 &, 000 \\
\hline & Bottom & 32 & 2,38 & ,414 & & & \\
\hline \multirow[t]{2}{*}{ Item 26} & Top & 32 & 4,05 & 1,521 & 77 & 5,000 &, 000 \\
\hline & Bottom & 32 & 3,45 & 273 & & & \\
\hline \multirow[t]{2}{*}{ Item 27} & Top & 32 & 3,65 & ,895 & 77 & 6,203 &, 000 \\
\hline & Bottom & 32 & 2,31 & 1,205 & & & \\
\hline \multirow[t]{2}{*}{ Item 28} & Top & 32 & 3,88 & 640 & 77 & 7,008 &, 000 \\
\hline & Bottom & 32 & 2,42 & 1,260 & & & \\
\hline \multirow[t]{2}{*}{ Item 29} & Top & 32 & 4,40 & 1,335 & 77 & 2,820 &, 000 \\
\hline & Bottom & 32 & 3,99 & ,326 & & & \\
\hline \multirow[t]{2}{*}{ Item 30} & Top & 32 & 3,01 & 1,840 & 77 & 3,014 & ,009 \\
\hline & Bottom & 32 & 2,81 & 1,653 & & & \\
\hline \multirow[t]{2}{*}{ Item 31} & Top & 32 & 3,24 & 1,401 & 77 & 2,019 & ,035 \\
\hline & Bottom & 32 & 2,37 & ,987 & & & \\
\hline Item 32 & Top & 32 & 3,04 & 1,612 & 77 & ,562 & ,171 \\
\hline & Bottom & 32 & 3,37 & ,956 & & & \\
\hline Item 33 & Top & 32 & 4,20 & 814 & 77 & 2,656 &, 000 \\
\hline & Bottom & 32 & 3,11 & 1,063 & & & \\
\hline Item 34 & Top & 32 & 3,31 & 1,058 & 77 & 2,210 &, 000 \\
\hline & Bottom & 32 & 2,42 & 1,783 & & & \\
\hline Item 35 & Top & 32 & 3.47 & ,784 & 77 & 3,921 &, 000 \\
\hline & Bottom & 32 & 2,55 & 1,302 & & & \\
\hline Item 36 & Top & 32 & 3,37 & 1,354 & 77 & 5,979 &, 001 \\
\hline & Bottom & 32 & 2,94 & ,598 & & & \\
\hline Item 37 & Top & 32 & 3,98 & ,887 & 77 & 6,544 & ,120 \\
\hline & Bottom & 32 & 3,43 & ,740 & & & \\
\hline Item 38 & Top & 32 & 3,42 & 1,963 & 77 & 4,225 &, 000 \\
\hline & Bottom & 32 & 3,04 & 1,621 & & & \\
\hline Item 39 & Top & 32 & 3,42 & 1,874 & 77 & 3,944 &, 000 \\
\hline & Bottom & 32 & 2,07 & 1,560 & & & \\
\hline Item 40 & Top & 32 & 3,44 & 1,204 & 77 & 2,550 &, 000 \\
\hline & Bottom & 32 & 3,12 & 1,304 & & & \\
\hline Item 41 & Top & 32 & 3,77 & 1,950 & 77 & 6,954 & ,000 \\
\hline
\end{tabular}




\begin{tabular}{llllllll}
\hline & Bottom & 32 & 3,01 &, 227 & & & \\
Item 42 & Top & 32 & 3,50 & 1,704 & 79 & 4,210 &, 000 \\
& Bottom & 32 & 3,20 &, 987 & & & \\
Item 43 & Top & 32 & 4,58 & 1,126 & 79 & 3,054 &, 000 \\
& Bottom & 32 & 4,01 & 1,357 & & & \\
Item 44 & Top & 32 & 3,22 &, 360 & 79 & 1,587 &, 163 \\
& Bottom & 32 & 3,29 &, 350 & & & \\
Item 45 & Top & 32 & 3,63 & 1,354 & 79 & 3,874 &, 000 \\
& Bottom & 32 & 3,21 &, 417 & & & \\
Item 46 & Top & 32 & 3,72 & 1,665 & 79 & 7,012 &, 001 \\
& Bottom & 32 & 2,87 & 1,060 & & & \\
Item 47 & Top & 32 & 4,31 & 1,470 & 79 & 5,878 &, 000 \\
& Bottom & 32 & 3,73 &, 455 & & & \\
Item 48 & Top & 32 & 4,64 & 1,235 & 79 & 7,655 &, 000 \\
& Bottom & 32 & 3,80 & 1,056 & & & \\
Item 49 & Top & 32 & 3,71 &, 322 & 79 & 6,138 &, 000 \\
& Bottom & 32 & 3,20 & 1,221 & & & \\
Item 50 & Top & 32 & 4,36 &, 553 & 79 & 5,818 &, 000 \\
& Bottom & 32 & 2,90 &, 931 & & & \\
Item 51 & Top & 32 & 3,24 & 1,020 & 79 & 3,545 &, 000 \\
& Bottom & 32 & 3,17 &, 585 & & & \\
Item 52 & Top & 32 & 4,24 &, 663 & 79 & 5,091 &, 000 \\
& Bottom & 32 & 3,71 & 1,206 & & & \\
Item 53 & Top & 32 & 2,64 & 1,530 & 79 & 6,058 &, 000 \\
& Bottom & 32 & 2,71 &, 930 & & & \\
Item 54 & Top & 32 & 4,24 & 1,201 & 79 & 5,542 &, 000 \\
& Bottom & 32 & 3,22 &, 780 & & & \\
\hline
\end{tabular}

T test results are shown in Table 8. In Table 8, top or bottom groups are divided according to the level of the texts for being for the child rights, and the number of the participants $(\mathrm{N})$, the mean $(\mathrm{X})$, standard deviation $(\mathrm{S})$, degree of freedom (d.f), T Statistics (t Value) and significance level(p) of each group are shown. So as to decide according to the test results in Table 8, $p$ or $t$ values are regarded. If $p$ is lower than $0.05(p<0.05)$ at the significance level of 0.05 , the difference between the groups are important. In other words, the given item, basing upon the total points, significantly discriminates the top group which is in the top $27 \%$ of the sample and the group which is in the bottom $27 \%$ of the sample.

When Table 8 is examined, it is understood that the significance level of the items numbered $5,8,32,37$ and 44 is higher than 0,05 . The fact that item-total score correlation coefficients of these items are also lower than 0,30 shows that these items are needed to be extracted from the scale. It is decided to extract items numbered 5, 8, 32, 37 and 44 from this draft scale depending on the $\mathrm{T}$ test results. Thus, there are 49 items in the $3^{\text {rd }}$ draft scale to be studied with the main sample.

The lowest item-total coefficient among these 49 items is 0,$325 ; \mathrm{t}$ test values of these items vary between 2,019 and 7,655. In second pilot study, internal consistency of the $2^{\text {nd }}$ draft consisting of 54 items was determined as $\alpha=0,826$ and after above-mentioned items were extracted, internal consistency of the $3^{\text {rd }}$ draft scale consisting of 49 items was determined as $\alpha=0,842$. Thus it was seen that a scale of 49 items which had relatively high reliability was achieved.

\subsubsection{Main Sample Study}

As a result of the pilot study and item analyses related the pilot study, $3^{\text {rd }}$ draft scale consisting of 49 items was achieved. So as to perform factor analyses of this draft, a 600-people sample group was aimed and these drafts were delivered to the 500 participants by hand and to 110 participants via e-mail.

458 of the handed scales and 62 of the scales sent via e-mail returned and following to the evaluations 510 of them were accepted to be valid. Main sample study was performed between February and April, 2018.

In table 9, there are some descriptive statistics related to the range of the scores of the Text Evaluation Scale for Child Rights. 
Table 9. Descriptive Values of the Text Evaluation Scale for Child Rights

\begin{tabular}{ll}
\hline Descriptive Statistics & \\
\hline $\mathbf{N}$ & 510 \\
Mean & 180,134 \\
Std. Error of Median & 4,59874 \\
Median & 158,00 \\
Mode & 154 \\
Std. Deviation & 20,98856 \\
Variance & 361,324 \\
Skewness &, 024 \\
Kurtosis &, 035 \\
Range & 190,00 \\
Minimum & 95,00 \\
Maximum & 230,00 \\
Sum & 91868,34 \\
\hline
\end{tabular}

Since there are 49 items in the Text Evaluation Scale for Child Rights, descriptive statistics of which are in Table 9, possible lowest score is 49 while the highest possible score is 245 . The range is expected to be (245-49=) 196 so that the scale could cover all of the skill items from the most positive point of the related skill to the most negative point of it; however, it can be seen that range is 190 in the pilot study. Now then, it is seen that the draft scale covers some parts of the expected range. The mean of the data, obtained in the pilot study as measures of central tendency, is 180,134; the median is 158 and the mode is 154 which are very close to each other. It is determined that range informing about how the data are distributed around the measures of central tendency is 190 while standard deviation is 20,98. Showing the distribution rates of points and values, these obtained measures of tendency has revealed that the participants of the pilot study are homogenous in terms of the assessed features.

The Text Evaluation Scale for Child Rights was studied with the main sample group consisting of 510 people and factor analysis was performed.

So as to perform factor analysis, Kaiser-Meyer-Olkin (KMO) test and Bartlett test was performed. In Table 10, the results of Kaiser-Meyer-Olkin (KMO) test and Bartlett test related to the Text Evaluation Scale for Child Rights are shown.

Table 10. The results of kaiser-meyer-olkin (kmo) Test and Bartlett Test Related to the Text Evaluation Scale for Child Rights

\begin{tabular}{|c|c|c|}
\hline \multicolumn{2}{|c|}{ Kaiser-Meyer-Olkin Measure of Sample Adequacy } & ,856 \\
\hline \multirow{3}{*}{ Bartlett's Test of Sphericity } & Approximate chi square & 16254,20 \\
\hline & Degree of freedom & 1325 \\
\hline & Significance level & ,004 \\
\hline
\end{tabular}

When Table 10 is examined it can be understood that KMO value (0.856) is adequate for the factor analysis of the size of the sample group and that the significance of the Bartlett values results from the multivariate normal distribution.

According to these obtained results, the size of the sample group is adequate for factor analysis. After it was determined that the size of the sample group is adequate for factor analysis, the next stage was to determine the factor number of the scale. At this stage, in order to determine the factor number, explained variance rate was examined and it was decided that the scale consisted of two factors. 
Table 11. The Variance Rates Explained by the Factors of the Text Evaluation Scale for Child Rights

\begin{tabular}{lccc}
\hline Factors & Eigenvalue & Variance (\%) & Cumulative Variance (\%) \\
\hline $\mathbf{1}^{\text {st }}$ Factor & 4,321 & 19,265 & 56,284 \\
$\mathbf{2}^{\text {nd }}$ Factor & 4,012 & 17,078 & 61,349 \\
$\mathbf{3}^{\text {rd }}$ Factor & 3,842 & 16,914 & 62,448 \\
\hline
\end{tabular}

When Table 11 was examined, it was determined that total variance rate was $\% 62,448$ which is an admissible value.

Following to the determination of the variance rates, Varimax rotation analyses were performed in order to determine the range of the items to the factors, and the results are shown in Table 12.

Table 12. Converted Constituents Matrix of the Text Evaluation Scale for Child Rights after the Factor Analysis

\begin{tabular}{|c|c|c|c|}
\hline $\begin{array}{c}\text { Item } \\
\text { Number }\end{array}$ & $\begin{array}{c}1^{\text {st }} \\
\text { Factor } \\
\end{array}$ & $\begin{array}{c}2^{\text {nd }} \\
\text { Factor } \\
\end{array}$ & $\begin{array}{c}3^{\text {rd }} \\
\text { Factor } \\
\end{array}$ \\
\hline 1 & ,812 & & \\
\hline 42 & ,824 & & \\
\hline 31 & ,830 & & \\
\hline 20 & ,784 & & \\
\hline 22 & ,745 & & \\
\hline 30 &, 710 & & \\
\hline 12 & ,705 & & \\
\hline 35 & 690 & ,682 & \\
\hline 40 & 684 & 677 & \\
\hline 2 & 670 & 675 & \\
\hline 27 & & 672 & \\
\hline 17 & & 668 & \\
\hline 8 & & 664, & \\
\hline 25 & & 660 & \\
\hline 32 & & 658 & \\
\hline 43 & & 655 & \\
\hline 39 & & 652 & \\
\hline 37 & & 549, & \\
\hline 3 & & 645, & \\
\hline 33 & & 641 & \\
\hline 47 & & 635, & \\
\hline 6 & & 627 & \\
\hline 38 & & 624 & \\
\hline 46 & & 620 & \\
\hline 18 & & 615 & \\
\hline 34 & & 613 & \\
\hline 21 & & 608, & \\
\hline 4 & & 605 & \\
\hline 16 & & ,580 & \\
\hline 29 & & ,578 & \\
\hline 13 & & ,550 & \\
\hline 9 & &, 551 & \\
\hline 11 & & ,547 & \\
\hline
\end{tabular}




\begin{tabular}{ccc}
\hline $\mathbf{3 6}$ &, 521 & \\
$\mathbf{4 4}$ &, 518 & \\
$\mathbf{2 3}$ &, 514 & \\
$\mathbf{1 9}$ &, 510 & \\
$\mathbf{4 5}$ &, 502 & \\
$\mathbf{2 8}$ &, 490 & \\
$\mathbf{5}$ &, 485 & \\
$\mathbf{4 1}$ &, 479 & \\
$\mathbf{2 4}$ &, 467 & \\
$\mathbf{1 5}$ &, 464 & \\
$\mathbf{4 8}$ &, 431 & \\
$\mathbf{7}$ & &, 689 \\
$\mathbf{1 0}$ & &, 664 \\
$\mathbf{4 9}$ &, 590 &, 594 \\
$\mathbf{2 6}$ & &, 430 \\
$\mathbf{1 4}$ & &, 420 \\
\hline
\end{tabular}

As it can be seen in Table 12, when the range of the items to the factors is examined through the Varimax rotation analysis technique, items except for numbered 14, 26 and 48 have higher values $(>, 45)$ in the factors they belong to. It is seen that 4 items (numbered 2, 35, 40,49) get loading from more than one factor and that factor loadings are lower than 0,10 in the factors they belong to. It was decided to extract these items from the scale. Thus, total 42 items left in 3 factors in the scale. Due to the fact that two items are not enough to explain one factor and that there were only 2 items in the $3^{\text {rd }}$ factor, 2 remained items (numbered 14 and 26) was decided to be extracted from the scale.

It is necessary to determine whether data structure is adequate for factor analysis so as to repeat factor analysis for the Text Evaluation Scale for Child Rights. Thus, once again, Kaiser-Meyer-Olkin (KMO) test and Bartlett test techniques were utilized. (Balc1, 2013; Kalayc1, 2005).

Table 13. Kaiser-meyer-olkin (kmo) Test and Bartlett Test Results for the Text Evaluation Scale for Child Rights

\begin{tabular}{lll}
\hline Kaiser-Meyer-Olkin Measure of Sample Adequacy & $\mathbf{8 7 6}$ \\
\hline \multirow{3}{*}{ Bartlett's Test of Sphericity } & Approximate chi square & 16267,60 \\
& Degree of freedom & 1364 \\
& Significance level &, 004 \\
\hline
\end{tabular}

KMO test determines whether chosen sample data is adequate for revealing factors. That test value varying between 0 and 1 is high (0.876) means that every variable could be well estimated by other variables in the scale. In a case that $\mathrm{KMO}$ value equals to 0 or close to 0 indicates that there is dispersion in the range of the correlation coefficients and that factor analysis cannot be performed on these values. Bartlett's Test of Sphericity value provides chi square statistic value. The fact that significance level is lower than ,05 in this test means that data structure is adequate for revealing factors. As it can be seen in Table 13, that $\mathrm{KMO}$ result is ,876 and Bartlett significance value is 0,004 offers that factor analysis could be continued.

When Table 14 is examined, according to the range of the items to the factors via the Varimax rotation analysis technique, it was determined that all items have higher values $(>, 45)$ in the factors that they belong to.

According to the results of the analysis, sub-dimensions of the Text Evaluation Scale for Child Rights and the items which have loading from these sub-dimensions. 
Table 14. Converted Constituents Matrix of the Text Evaluation Scale for Child Rights after the Factor Analysis

\begin{tabular}{|c|c|c|}
\hline $\begin{array}{c}\text { Item } \\
\text { Number }\end{array}$ & $1^{\text {st }}$ Factor & $2^{\text {nd }}$ Factor \\
\hline 1 &, 823 & \\
\hline 9 & ,709 & \\
\hline 16 & ,791 & \\
\hline 18 & ,750 & \\
\hline 25 & 718, & \\
\hline 26 & ,837 & \\
\hline 35 & 831, & \\
\hline 2 & & ,675 \\
\hline 3 & & 624, \\
\hline 4 & &, 501 \\
\hline 5 & & 632, \\
\hline 6 & & ,669 \\
\hline 7 & & ,560 \\
\hline 8 & &, 552 \\
\hline 10 & & ,562 \\
\hline 11 & & ,469 \\
\hline 12 & & ,594 \\
\hline 13 & & ,677 \\
\hline 14 & & ,619 \\
\hline 15 & &, 518 \\
\hline 17 & & 613 \\
\hline 19 & &, 520 \\
\hline 20 & & ,474 \\
\hline 21 & & ,667 \\
\hline 22 & & 679, \\
\hline 23 & &, 501 \\
\hline 24 & & ,588 \\
\hline 27 & & ,667 \\
\hline 28 & & 654, \\
\hline 29 & & ,619 \\
\hline 30 & & ,530 \\
\hline 31 & &, 555 \\
\hline 32 & & 632, \\
\hline 33 & & 661 \\
\hline 34 & & ,488 \\
\hline 36 & & ,664 \\
\hline 37 & & ,525 \\
\hline 38 & &, 515 \\
\hline 39 & & ,629 \\
\hline 40 & & 647 \\
\hline
\end{tabular}


Table 15. Sub-dimensions of the Text Evaluation Scale for Child Rights and the Items Which Have Loading from These Sub-Dimensions

\begin{tabular}{lcc}
\hline Factors & The number of the items & Item Number \\
\hline 1. Author & 7 & $1,9,16,18,25,26,35$ \\
\hline & & $2,3,4,5,6,7,8,10,11,12$, \\
2. Content & 33 & $13,14,15,17,19,20,21,22$, \\
& & $23,24,27,28,29,30,31,32$, \\
& & $33,34,36,37,38,39,40$ \\
\hline
\end{tabular}

When Table 15 is examined it is seen that first factor consists of 7 items while second factor is consisting of 33 items. After the items in the factors were determined, they were examined and sub-dimensions were named. In this regard, first sub-dimension was named as author and second one was named as content.

\subsection{Reliability Analyses}

While evaluating the reliability of the Text Evaluation Scale for Child Rights, Cronbach Alpha, Spearman-Brown and Guttman internal consistency coefficients were calculated.

Table 16. Internal Consistency Coefficients of the Text Evaluation Scale for Child Rights

\begin{tabular}{lll}
\hline & $\mathbf{r}$ & $\mathbf{p}$ \\
\hline Cronbach Alpha & 0,901 & $\mathrm{p}<0,05$ \\
Spearman-Brown & 0,890 & $\mathrm{p}<0,05$ \\
Guttman & 0,859 & $\mathrm{p}<0,05$ \\
\hline
\end{tabular}

When the table is examined, it is understood that Cronbach Alpha value is 0,901; Spearman-Brown value is 0,890 and Guttman value is 0,859 . Due to the fact that all internal consistency coefficients are higher than the value of 0,80 , it can be claimed that the reliability of the Text Evaluation Scale for Child Rights is high (Bademci, 2006; Özer\&Dönmez, 2013; Karakoç\&Dönmez, 2014). In short, all of the items in the Text Evaluation Scale for Child Rights aim to assess the same feature.

Since the scale consists of two factors, internal consistency values of the factors are given separately.

Table 17. Internal Consistency Values of the Factors Belonging to the text Evaluation Scale for Child Rights

\begin{tabular}{|c|c|c|c|c|c|}
\hline Factors & $\begin{array}{c}\text { The } \\
\text { Number of } \\
\text { the Items }\end{array}$ & Item Number & & $\mathbf{r}$ & $\mathbf{p}$ \\
\hline Author & 7 & $1,9,16,18,25,26,35$ & $\begin{array}{l}\text { Cronbach Alpha } \\
\text { Spearman-Brown } \\
\text { Guttman }\end{array}$ & $\begin{array}{l}0,822 \\
0,814 \\
0,800\end{array}$ & $\begin{array}{l}\mathrm{p}<0,05 \\
\mathrm{p}<0,05 \\
\mathrm{p}<0,05\end{array}$ \\
\hline Content & 33 & $\begin{array}{l}2,3,4,5,6,7,8,10,11,12,13, \\
14,15,17,19,20,21,22,23, \\
24,27,28,29,30,31,32,33, \\
34,36,37,38,39,40\end{array}$ & $\begin{array}{l}\text { Cronbach Alpha } \\
\text { Spearman-Brown } \\
\text { Guttman }\end{array}$ & $\begin{array}{l}0,834 \\
0,810 \\
0,802\end{array}$ & $\begin{array}{l}\mathrm{p}<0,05 \\
\mathrm{p}<0,05 \\
\mathrm{p}<0,05\end{array}$ \\
\hline
\end{tabular}

When Table 17 is examined, it is seen that the values for the factors author and content are higher than the value of 0,80. It also means that factors belonging to the Text Evaluation Scale for Child Rights are highly reliable.

Following to the reliability studies, items from each dimension were gathered, and reversely graded negative items were marked with red color and thus the scale was put into its final form. The scale was given in Appendix 1.

\section{Discussion}

The Text Evaluation Scale for Child Rights is a 5 point Likert scale developed to fill in the gap in the field. The theoretical framework of the scale is based on the United Nations Organization Child Rights Convention and 
additional protocols to this convention, besides, international attempts for child rights, conventions, studies regarding the subject in the literature are also taken into consideration.

This scale, which could evaluate whether the texts developed for children or used for the education of children are suitable for child rights, consists of two sub dimensions and 40 items. The lowest possible score in the text is 40 while the highest possible score is 200. In the sub-dimension of the author, the attitude of the writer towards child rights is evaluated while child rights in the text are evaluated in the sub-dimension of content.

Regarding the sub-dimensions of the scale, the fact that Cronbach Alfa reliability coefficient is high (author sub-dimension $=0,822$; content sub-dimension $=0,834$ ) indicates that the items in the sub-dimension are consistent with each other. For the whole of the scale, it was determined that Cronbach Alfa value was 0,90; Spearman-Brown value was 0,890 and Guttman value was 0,859. It means that the scale is highly reliable (Bademci, 2006; Özer\&Dönmez, 2013; Karakoç\&Dönmez, 2014; Büyüköztürk, 2002; Gorsuch, 1983). That Cronbach Alfa reliability coefficient is higher than the coefficients related to the sub-dimensions can be interpreted as a fact that the scale could be used both unidimensional and multidimensional (Bozanoğlu, 2004). In the Text Evaluation Scale for Child Rights, there are items whose factor loading value is higher than 0,45 . It is seen that the scale, which was developed according to the validity and reliability results, could be utilized to determine whether texts are adequate for child rights.

\section{Conclusion}

As a result of the fact that there are not studies similar to the Text Evaluation Scale for Child Rights in the literature, even though there are attitude scales for child rights or only book/text evaluation scales, there could not be found any chance to compare the scale directly.

It could be presented as a suggestion to test the scale with different sample groups since the sample group of the study was limited to undergraduates, teachers and academicians. Moreover, the books used for child education and the books suggested by official institutions and organizations could be evaluated with the help of the scale. Thus, education materials and books prepared for children could be provided with sensitivity to respect the child rights, furthermore, child rights education might be given prominence in the contents of the given materials and books.

\section{References}

Adeyemi Stephen, B., Funmilayo Roseline, O., \& Ocheje, C. B. (2015). Effective knowledge development in secondary schools educational level in contemporary information age: assessment of availability of electronic information resources in nigerian school libraries. Journal of Education and e-Learning Research, 2(4), 72-78.

Akyüz, E. (2010). Child law. Ankara: Pegem Akademi.

Bademci, V. (2006). Ending the argument: cronbach's alpha coefficient can be used with two valued $[0,1]$ measured items. Journal of Kazım Karabekir Education Faculty, 13, 438-46.

Balc1, S. (2013). A scale study that determines the attitudes of the students who study by "pilot application of tablet pc" in Turkish lesson. Turkish Studies, 8(1), 855-870

Bozanoğlu, İ. (2004). Academic motivation scale: Development, reliability, validity. Ankara University, Journal of Faculty of Educational Sciences, 37(2), 83-98.

Büyüköztürk, Ş. (2002). Data analysis handbook for social sciences. Ankara: Pegem A.

Creswell, J. W., \& Plano Clark, V. L. (2014). Mixed method research. (Trans. Edt. Yüksel Dede\& Selçuk Beşir Demir). Anı: Ankara.

DeVellis, R. F. (2003). Scale development: Theory and application (2nd Ed.). Applied Social Research Methods Series, Vol. 26, London: Sage.

Erdemir, E. (2007). Candidate focused staffing: Conceptual framework and scale development. Unpublished, Doctorate Thesis. Eskişehir: Eskişehir Anadolu Univercity Social Since İnstitute.

Gorsuch, R. L. (1983). Factor analysis. Hillsdale: Lawrence Erlbaum Associates.

Gündoğan, G., \& Günay, M. (2004). İnsan haklart ve eğitimi. İzmir: İlya.

Hinkin, T. R. (1995). A review of scale development practices in the study of organizations. Journal of Management, 21(5), 967-988. https://doi.org/10.1177/014920639502100509 
Kalaycı, Ş. (2005). SPSS uygulamalı çok değişkenli istatistik teknikleri. Ankara: Asil.

Kara, B., Biçer, Ü., \& Gökalp, A. S. (2004). Child exploitation. Journal of Child Health and Diseases, 47, 140-151.

Karakoç, F. Y., \& Dönmez, L. (2014). Basic principles of scale development. Medical Education World (Tıp Eğitimi Dünyast), 40, 39-49.

Kurt, S. L. (2013). Awareness of children's rights in Turkey. Unpublished, MA Thesis. Ankara: Ufuk Üniversitesi Sosyal Bilimler Enstitüsü.

Lawshe, C. H. (1975). A quantitative approach to content validity 1. Personnel psychology, $28(4), 563-575$. https://doi.org/10.1111/j.1744-6570.1975.tb01393.x

MEB. (1991). The united nations organization convention on the rights of the child. Ankara: Milli Eğitim.

Migdadi, A. İ.M., \& A., Baniabdelrahman. (2016). The effect of using team teaching on jordanian efl eleventh grade students' reading comprehension and their attitudes towards this strategy. Journal of Education and e-Learning Research, 3(2), 38-50.

Müftü, G. (2001). Rights of the Child. Journal of National Education, 151, 1-11.

Oriogu, C. D. (2015). Catch them young: developing and 1mproving of school libraries and reading habit of secondary school students in Nigeria. Journal of Education and e-Learning Research, 2(4), 60-63.

Özer, N., \& Dönmez, B. (2013). Surveillance cameras \& school safety: a scale development study. Turkish Studies, $8(3), 437-448$.

Özgüven, İ.E. (2012). Psychological tests. (11th ed.). Ankara: Nobel.

Sevim, O. (2014). developing the academic ethics values scale: the reliability and validity study. Turkish Studies, 9(6), 943-957. https://doi.org/10.7827/TurkishStudies.6969

Şahin, F. (2009). Managerial resourcefulness: A study about conceptualizing and measuring it as a component of effective management and leadership. Unpublished, Doctorate Thesis, Niğde: Niğde Univercity Social Since İnstitute.

Şeker, H., \& Gençdoğan, B. (2006). Developing measurement tool in education and psychology. Ankara: Nobel.

Şencan, H. (2005). Reliability and validity. Ankara: Seçkin.

Torun, F. (2011). Effect of game method on success, permanence and attitude in childrens rights education, Unpublished, Master's Thesis, Adıyaman: Adıyaman Univercity Social Since İnstitute.

Veneziano, L., \& Hooper, J. (1997). Method for quantifying content of healt-related questionnaires. American Journal of Healt Behavior, 21(1), 67-70.

Yıldırım, S., \& Kılıç, Ü. (2018). Education and training in the classical Ottoman state. Journal of Graduate School of Social Sciences, 22(Özel Say1), 603-627.

Yurdugül, H. (2005). Using scope validity indices for scope validation in scale development studies. XIV. National Educational Science Congress. Denizli: Pamukkale Univercity Education Faculty.

Yurtsever, M. (2009). The development of parental attitudes scale for children's rights and the examination of parental attitudes for their children's rights in terms of different variables. Unpublished, Doctorate Thesis. İstanbul: Marmara Univercity Education Since İnstitute. 
Appendix 1. The text evaluation scale for child rights

\section{THE TEXT EVALUATION SCALE FOR CHILD RIGHTS}

\begin{tabular}{|c|c|c|c|c|c|c|c|}
\hline & & & 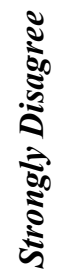 & 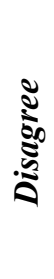 & 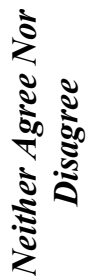 & $\overbrace{\infty}^{\infty}$ & 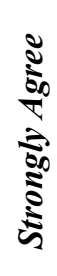 \\
\hline \multirow{18}{*}{$\begin{array}{l}\text { 量 } \\
\text { 量 } \\
\text { ○ }\end{array}$} & 1. & $\begin{array}{l}\text { Visuals provided on the cover/ before the text are } \\
\text { suitable for the mental health of the child. }\end{array}$ & & & & & \\
\hline & 2. & $\begin{array}{l}\text { The text is a publishing for protecting child's physical } \\
\text { and cognitive health. }\end{array}$ & & & & & \\
\hline & 3. & $\begin{array}{l}\text { The text emphasizes the equality of opportunity in } \\
\text { education. }\end{array}$ & & & & & \\
\hline & 4. & $\begin{array}{l}\text { The text has enough qualifications to educate children } \\
\text { against abuse }\end{array}$ & & & & & \\
\hline & 5. & $\begin{array}{l}\text { In the text, every individual is accepted/ described as a } \\
\text { child until they are } 18 \text {. }\end{array}$ & & & & & \\
\hline & 6. & $\begin{array}{l}\text { In the text, parents are advisors for the child's } \\
\text { development. }\end{array}$ & & & & & \\
\hline & 7. & $\begin{array}{l}\text { In the text, a connective tone (language, religion, nation } \\
\text { etc.) is adopted. }\end{array}$ & & & & & \\
\hline & 8. & In the text, child is called/placed by his/her name. & & & & & \\
\hline & 9. & $\begin{array}{l}\text { In the text, the communication right of the child is } \\
\text { respected. }\end{array}$ & & & & & \\
\hline & 10. & $\begin{array}{l}\text { In the text, child is given a chance to express his/her } \\
\text { opinion freely via an instrument he/she will choose. }\end{array}$ & & & & & \\
\hline & 11. & $\begin{array}{l}\text { In the text, the data which belong to the child's identity } \\
\text { are respected (name, allegiance, family bonds etc.) }\end{array}$ & & & & & \\
\hline & 12. & $\begin{array}{l}\text { In the text, the inherent right to life of the child is } \\
\text { respected. }\end{array}$ & & & & & \\
\hline & 13. & $\begin{array}{l}\text { Some statements/expressions which violate child rights } \\
\text { were located in the text. }\end{array}$ & & & & & \\
\hline & 14. & $\begin{array}{l}\text { Some visuals which could cause child abuse were used } \\
\text { in the text. }\end{array}$ & & & & & \\
\hline & 15. & $\begin{array}{l}\text { Some implications which could cause child abuse exist } \\
\text { in the text }\end{array}$ & & & & & \\
\hline & 16. & $\begin{array}{l}\text { In the text, a manner that tolerates child abuse is the } \\
\text { point. }\end{array}$ & & & & & \\
\hline & 17. & $\begin{array}{l}\text { The encouragement of child marriage is not the point in } \\
\text { the text. }\end{array}$ & & & & & \\
\hline & 18. & In the text, the child is imaged as a sex object & & & & & \\
\hline
\end{tabular}




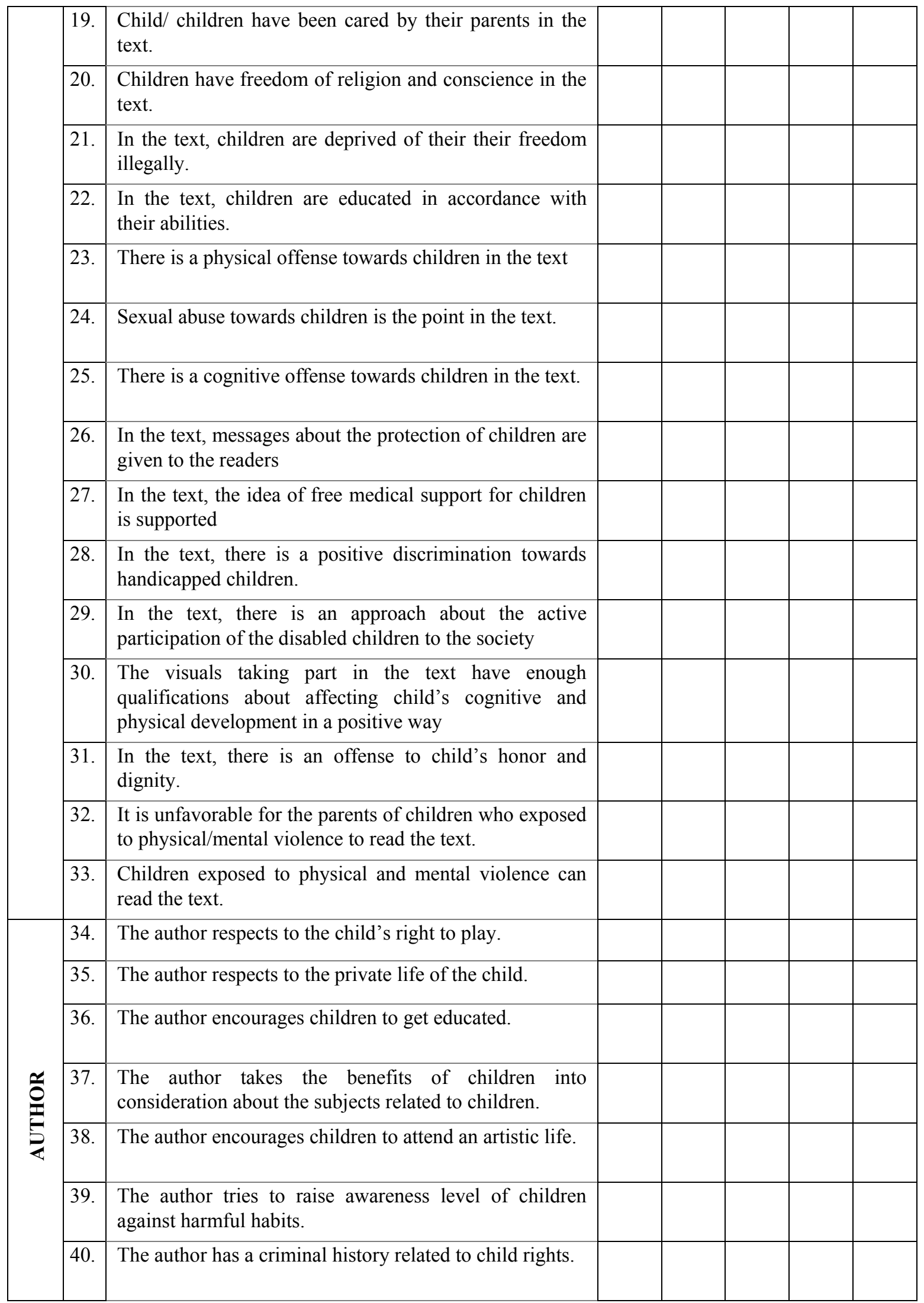

